\title{
Greenhouse gas emissions from laboratory-scale fires in wildland fuels depend on fire spread mode and phase of combustion
}

\author{
N. C. Surawski ${ }^{1}$, A. L. Sullivan ${ }^{1}$, C. P. Meyer $^{2}$, S. H. Roxburgh ${ }^{1}$, and P. J. Polglase ${ }^{1}$ \\ ${ }^{1}$ CSIRO Land and Water Flagship and Agriculture Flagship, Clunies Ross St, Acton, ACT 2601, Australia \\ ${ }^{2}$ CSIRO Oceans and Atmosphere Flagship, Station St, Aspendale, VIC 3195, Australia \\ Correspondence to: N. C. Surawski (nicholas.surawski@ csiro.au)
}

Received: 4 August 2014 - Published in Atmos. Chem. Phys. Discuss.: 8 September 2014

Revised: 17 April 2015 - Accepted: 20 April 2015 - Published: 13 May 2015

\begin{abstract}
Free-burning experimental fires were conducted in a wind tunnel to explore the role of ignition type and thus fire spread mode on the resulting emissions profile from combustion of fine ( $<6 \mathrm{~mm}$ in diameter) Eucalyptus litter fuels. Fires were burnt spreading with the wind (heading fire), perpendicular to the wind (flanking fire) and against the wind (backing fire). Greenhouse gas compounds (i.e. $\mathrm{CO}_{2}, \mathrm{CH}_{4}$ and $\mathrm{N}_{2} \mathrm{O}$ ) and $\mathrm{CO}$ were quantified using off-axis integratedcavity-output spectroscopy. Emissions factors calculated using a carbon mass balance technique (along with statistical testing) showed that most of the carbon was emitted as $\mathrm{CO}_{2}$, with heading fires emitting $17 \%$ more $\mathrm{CO}_{2}$ than flanking and $9.5 \%$ more $\mathrm{CO}_{2}$ than backing fires, and about twice as much $\mathrm{CO}$ as flanking and backing fires. Heading fires had less than half as much carbon remaining in combustion residues. Statistically significant differences in $\mathrm{CH}_{4}$ and $\mathrm{N}_{2} \mathrm{O}$ emissions factors were not found with respect to fire spread mode. Emissions factors calculated per unit of dry fuel consumed showed that combustion phase (i.e. flaming or smouldering) had a statistically significant impact, with $\mathrm{CO}$ and $\mathrm{N}_{2} \mathrm{O}$ emissions increasing during smouldering combustion and $\mathrm{CO}_{2}$ emissions decreasing. Findings on the equivalence of different emissions factor reporting methods are discussed along with the impact of our results for emissions accounting and potential sampling biases associated with our work. The primary implication of this study is that prescribed fire practices could be modified to mitigate greenhouse gas emissions from forests by judicial use of ignition methods to induce flanking and backing fires over heading fires.
\end{abstract}

\section{Introduction}

Wildfires emit a variety of pollutants to the atmosphere which have impacts on global warming, biogeochemical cycles, ambient air quality and human health (Mack et al., 2011; Monks et al., 2009; Weinhold, 2011). Globally, wildfires contribute approximately $23 \%$ of total anthropogenic greenhouse gas equivalent emissions (Houghton et al., 2009; van der Werf et al., 2010) although there can be significant year-to-year variability. Furthermore, increases in wildfire occurrence have been observed in many parts of the world during the last decade, including the western United States (Running, 2006), the Mediterranean region (Portugal, Spain and Greece) (Vicente et al., 2011) and Australia (Cai et al., 2009).

The main greenhouse gas species of interest emitted by wildfire include $\mathrm{CO}_{2}, \mathrm{CH}_{4}$ and $\mathrm{N}_{2} \mathrm{O}$. Wildfires also emit particulate matter (PM) to the atmosphere that has an impact on climate due to its ability to absorb and scatter light (Reid et al., 2005). In addition, the effect of wildfire PM on the aerosol indirect effect (i.e. cloud formation) remains poorly quantified at present (Bowman et al., 2009).

Despite considerable progress since the pioneering works on emissions from biomass burning by Crutzen et al. (1979), and Seiler and Crutzen (1980), only recently has the chemical composition of biomass burning smoke been quantified in detail. Yokelson et al. (2013) deployed a Fourier transform infrared spectrometer (FTIR) and a range of different mass spectrometry systems to quantify 204 trace gas species, with a further 153 species being quantified but not able to be identified from the resulting mass spectra. Most of these compounds were non-methane hydrocarbons which play a 
role in ozone and secondary organic aerosol formation (Akagi et al., 2011). Based on this work, there now appears to be detailed knowledge on the chemical composition of smoke from biomass burning from fuels located in the south-east and south-west of the United States. Despite this new knowledge, measurements of $\mathrm{N}_{2} \mathrm{O}$ emissions from biomass burning are not commonly reported (Meyer and Cook, 2015).

The various sections of free-burning wildland fire perimeters propagate with three distinct orientations in response to the prevailing wind direction. Fire perimeters can propagate with the wind (i.e. a heading fire), against the wind (i.e. a backing fire) and perpendicular to the wind (i.e. a flanking fire) (Sullivan et al., 2012). The individual fire spread modes (i.e. heading, flanking and backing) within a larger overall fire exhibit different fire behaviour (such as different rates of spread, flame heights, combustion factors and fire line intensities) which could lead to differences in emissions with respect to fire spread mode (Sullivan and Ball, 2012).

Laboratory experiments testing the role of fire spread mode on fire behaviour and emissions have been conducted previously with Keene et al. (2006) referring to flanking fires as mixed combustion fires. Keene et al. (2006) reported differences in modified combustion efficiency (MCE) with different fire spread modes and report higher emissions factors for acetic acid $\left(\mathrm{CH}_{3} \mathrm{COOH}\right)$ for heading and flanking fires compared to backing fires. However, the only greenhouse gas compound measured in the study of Keene et al. (2006) was $\mathrm{CO}_{2}$, although detailed particulate emissions measurements were made.

In this study, we re-examine the burning methodology of Keene et al. (2006) in a controlled laboratory study involving a free-moving fire. We developed an explicit experimental design combined with statistical testing of results to examine the hypothesis that greenhouse gas emissions could depend on fire spread mode. The validity of this hypothesis has the implication that if emissions were dependent on fire spread mode, opportunities could open up to dramatically improve the precision with which greenhouse gas estimates of wildfire events are made and, perhaps more importantly, to strategically manage prescribed burning operations in forested landscapes to minimise greenhouse gas emissions by changing the applied fire spread mode of such fires.

In this study, the impact of fire spread mode on greenhouse gas $\left(\mathrm{CO}_{2}, \mathrm{CH}_{4}\right.$ and $\left.\mathrm{N}_{2} \mathrm{O}\right)$ emissions (plus $\mathrm{CO}$ ) profiles from the combustion of dry eucalypt forest litter was tested in a combustion wind tunnel facility. Dry eucalypt forest fuel was selected for this study as it is the dominant flora of southeastern Australia with this region being representative of fire activity in Australian temperate forests. Emissions estimates derived from this study build upon previous research efforts undertaken globally in temperate forest, where it is noted that emissions estimates from this ecological biome are rare in Australia (van Leeuwen and van der Werf, 2011).

In addition to testing the role of fire spread mode (i.e. heading, flanking and backing) on greenhouse gas emissions, the role of combustion phase (i.e. flaming or smouldering) and the temporal progression of emissions factors during a complete fire are explicitly tested with appropriate statistical methods. We also report findings on different methods for reporting emissions factors and demonstrate the impact of our results with reference to greenhouse gas emissions accounting from prescribed burning in Australia. Overall, the results from this study provide a new body of information on biomass burning emissions estimates from a region that has been poorly characterised in the past.

\section{Methodology}

\subsection{Combustion wind tunnel details}

Experiments were conducted in the CSIRO (Commonwealth Scientific and Industrial Research Organisation) Pyrotron (see Fig. 1) which is a $25.6 \mathrm{~m}$ long combustion wind tunnel facility designed to investigate the behaviour and emissions of laboratory-scale fires (Sullivan et al., 2013). Wind for experiments is generated upstream from the working section by a $1.372 \mathrm{~m}$ diameter centrifugal fan (model 54LSW) from Fans and Blowers Australia Pty Ltd. Positioned downstream of the fan in the settling section are four perforated screens and a flow straightener for removing as much turbulence from the air stream as possible (turbulence intensity $<0.6 \%$ ) (Sullivan et al., 2013). The working section, where fuel is placed for experimental burns and where combustion takes place, is $1.5 \mathrm{~m}$ wide and $4.8 \mathrm{~m}$ long. Gas phase emissions samples were obtained from the exit section of the wind tunnel, downstream of the working section. Two $12.7 \mathrm{~mm}$ diameter stainless steel tubes positioned at a height of $840 \mathrm{~mm}$ above the floor of the combustion wind tunnel were used to sample gas and particle phase samples separately. An array of $\mathrm{K}$ type thermocouples are positioned on the floor of the CSIRO Pyrotron with a spacing of $500 \mathrm{~mm}$ in the direction of wind flow with a least 11 thermocouples spanning the width of the working section to record temperatures at the flame base (Sullivan et al., 2013). The design of the CSIRO Pyrotron enables sampling from the plume of a low intensity free-moving fire, driven by the wind, which may be contrasted with the approaches used by, for example, Lobert et al. (1990), McMeeking et al. (2009) and Jenkins et al. (1993) which all involve stack sampling without capturing either the free-moving or wind-driven characteristics of wildland fires.

\subsection{Fuel collection and preparation}

Forest litter fuel was collected from Kowen Forest in the north-east of the Australian Capital Territory (ACT), Australia during late summer (see Fig. 2), in a stand dominated by Eucalyptus macrorhyncha (F. Muell.) and E. rossii (R.T. Bak. \& H.G. Sm.). The fine fuel ( $<6 \mathrm{~mm}$ diameter) litter layer was collected because it is the primary fuel layer com- 


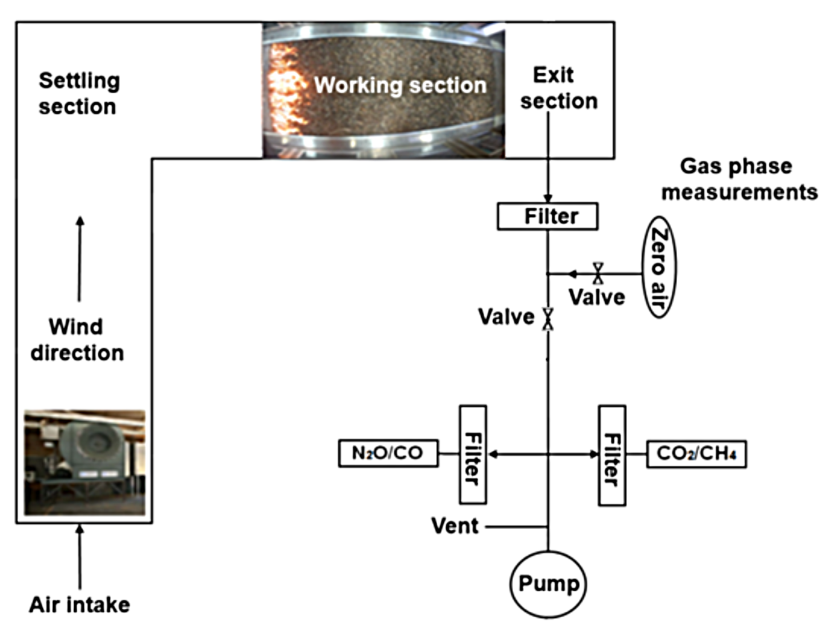

Figure 1. A schematic (not to scale) of the experimental configuration used in the CSIRO Pyrotron for experimental fires.

busted during forest fires in south-eastern Australia (Sullivan et al., 2012) and was comprised of leaf, bark and twig components. An attempt was made during the fuel collection not to include coarse fuel elements (such as large pieces of bark, twigs, logs and branches) greater than $6 \mathrm{~mm}$ in diameter. Fuel was sieved after collection to remove coarse fuel fractions that were not removed in the field. Fuel sieving also removed fragmented material from the soil fermentation layer which can affect the ability of a fire to propagate and its combustion phase.

A dry fine fuel load of $1.1 \mathrm{~kg} \mathrm{~m}^{-2}$ (or $11 \mathrm{tha}^{-1}$ ) was used which is typical of dry sclerophyll forest and is equivalent to that experienced during a major Australian wildfire (the 2009 Kilmore East fire) in dry sclerophyll forest (with a low understorey) in Victoria (Cruz et al., 2012). The moisture content of the fuel was measured prior to weighing to ensure that the correct dry fuel weight was achieved. Fuel moisture measurements before fuel drying were performed with a Wiltronics fine fuel moisture meter (Chatto and Tolhurst, 1997) which uses the electrical resistance of a plant sample to measure its water content.

After weighing out the fuel with ambient moisture content it was dried in an oven at $50{ }^{\circ} \mathrm{C}$ for $24 \mathrm{~h}$ to reduce the fuel moisture content to a level typical of that for fine fuels during major Australian wildfires ( $<5 \%$ oven-dry weight) (Cruz et al., 2012; McArthur, 1967; Sullivan and Matthews, 2013). Prior to each experimental burn, three to five subsamples were collected in tins from the fuel bed to measure the fuel moisture content. The tins were oven-dried at $105^{\circ} \mathrm{C}$ for $24 \mathrm{~h}$ (Matthews, 2010) with fuel moisture contents between 4.6 and $6.8 \%$ being achieved (see Table 1).

Fuel was spread in the working section of the wind tunnel to make the fuel bed as homogeneous as possible in terms of depth and the structural arrangement of leaf, bark and twig components. Mean fuel depths were between 24.2 and

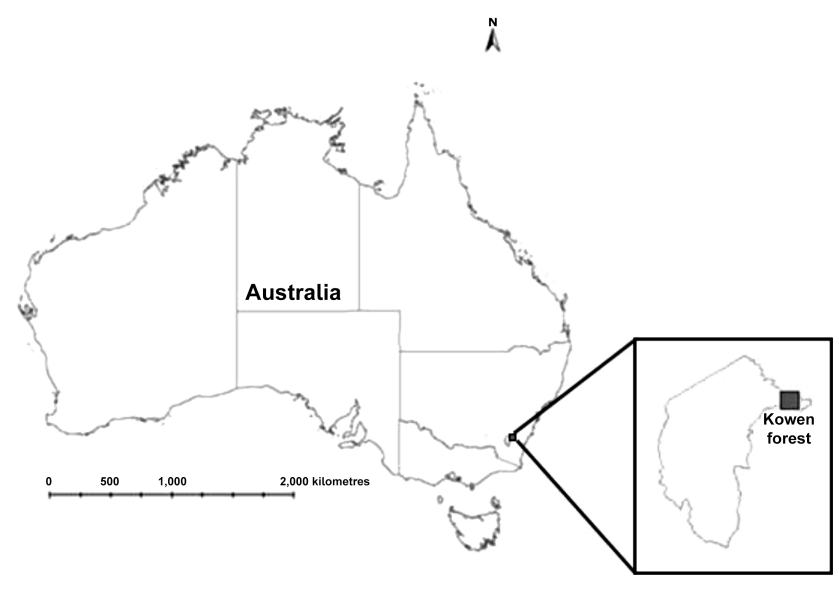

Figure 2. Location of the dry sclerophyll eucalypt forest for collection of litter $\left(35^{\circ} 19^{\prime} 30.07^{\prime \prime} \mathrm{S}, 149^{\circ} 15^{\prime} 25.64^{\prime \prime} \mathrm{E}\right)$. Shapefile of Australia sourced from the Department of Agriculture (2014).

$33.6 \mathrm{~mm}$ for the experimental fires. Three unburnt fuel samples were sorted and weighed throughout the course of the experiment to establish the relative proportions (by mass) of leaf $(23.2 \%)$, bark $(28.6 \%)$ and twig $(48.2 \%)$ components. The size of the fuel bed was $6 \mathrm{~m}^{2}(4 \mathrm{~m} \times 1.5 \mathrm{~m})$ for heading fires and $2.25 \mathrm{~m}^{2}(1.5 \mathrm{~m} \times 1.5 \mathrm{~m})$ for flanking and backing fires.

Fires were ignited using a $1.5 \mathrm{~m}$ channel filled with ethanol $(60 \mathrm{~mL}$ volume), which was placed in a different position (relative to the air flow) for each fire spread mode and lit with a gas lighter. Each fire spread mode was replicated six times (with the level of replication being based on Mulvaney, 2012) to enable the experimental uncertainty to be reduced to a satisfactory level. This level of replication resulted in a total of 18 fires. A wind speed of $1.5 \mathrm{~m} \mathrm{~s}^{-1}$ was used in all fire experiments. Altogether, the selection of fuel loads, fuel moisture content and wind speed were selected to achieve Byram fire line intensities (Byram, 1959) (which is the product of the lower heating value of the fuel, fuel consumed and the forward rate of spread) indicative of those during prescribed burning conditions in temperate eucalypt forest in Australia (i.e. approximately $<500 \mathrm{~kW} \mathrm{~m}^{-1}$ (Cheney, 1981), or approximately $<345 \mathrm{~kW} \mathrm{~m}^{-1}$ (McArthur, 1962)).

\subsection{Emissions measurements}

Gas phase measurements were performed using off-axis integrated-cavity-output spectroscopy (off-axis ICOS), a laser-based absorption technique used in commercially available instruments from Los Gatos Research (http://www. lgrinc.com/). One instrument measured $\mathrm{CO}_{2} / \mathrm{CH}_{4}$ (Greenhouse Gas Analyser GGA-24r-EP), and the other measured $\mathrm{N}_{2} \mathrm{O} / \mathrm{CO}\left(\mathrm{N}_{2} \mathrm{O} / \mathrm{CO}\right.$ Analyser 907-0015) with both instruments operating in slow flow mode. The method works by directing a laser beam into an optical cavity equipped with high reflectivity dielectric coated mirrors (with mirror losses 
Table 1. Summary of fire behaviour data from the experiments. Values are reported as the mean with the range reported as (minimum valuemaximum value). Byram fire line intensity is the product of the lower heating value of the fuel $\left(\mathrm{kJ} \mathrm{kg}^{-1}\right)$, fuel consumed (kg m$\left.{ }^{-2}\right)$ and the forward rate of spread $\left(\mathrm{m} \mathrm{s}^{-1}\right)$ (Byram, 1959).

\begin{tabular}{|c|c|c|c|c|c|c|c|c|}
\hline $\begin{array}{l}\text { Fire spread } \\
\text { mode }\end{array}$ & $\begin{array}{l}\text { Fuel moisture } \\
\text { content }(\%)\end{array}$ & $\begin{array}{l}\text { Fire duration } \\
\text { (s) }\end{array}$ & $\begin{array}{c}\text { Flaming } \\
\text { combustion } \\
\text { duration (s) }\end{array}$ & $\begin{array}{l}\text { Smouldering } \\
\text { combustion } \\
\text { duration (s) }\end{array}$ & $\begin{array}{l}\text { Rate of spread } \\
\quad\left(\mathrm{m} \mathrm{h}^{-1}\right)\end{array}$ & $\begin{array}{l}\text { Combustion } \\
\text { factor }(-)\end{array}$ & $\begin{array}{l}\text { Residue carbon } \\
\text { content }(\%)\end{array}$ & $\begin{array}{c}\text { Byram fire line } \\
\text { intensity } \\
\left(\mathrm{kW} \mathrm{m}^{-1}\right)\end{array}$ \\
\hline Heading & $5.6(5.0-6.8)$ & $715(580-840)$ & $256(224-290)$ & $459(356-582)$ & $123(103-150)$ & $81.8(77.7-84.4)$ & $33.3(29.4-66.2)$ & $553(462-693)$ \\
\hline Flanking & $5.6(5.1-6.2)$ & $1085(900-1530)$ & 907 (763-1099) & $178(93-431)$ & $6.6(4.9-8.2)$ & $71.6(61.3-81.7)$ & $54.0(39.2-67.7)$ & $26(17-32)$ \\
\hline Backing & $5.4(4.6-6.5)$ & $1413(1160-2230)$ & $1196(867-1988)$ & $218(72-533)$ & $6.1(4.2-7.5)$ & $82.2(77.3-86.4)$ & $72.8(34.8-78.9)$ & $27(20-32)$ \\
\hline
\end{tabular}

around $100 \mathrm{ppm}$ capable of being achieved) (Baer et al., 2002). The absorption signal is determined by the temporal decay (or "ringdown") of the light transmitted through the cavity due to absorption (based on the Beer-Lambert law) which is modelled as an exponential decay process (O'Keefe and Deacon, 1988).

Due to the highly reflective nature of the mirrors, optical path lengths of several kilometres can be achieved, making the technique highly suited for the detection of trace gas species (Baer et al., 2002). Off-axis ICOS is a relatively new method in cavity ring down spectroscopy that is simpler to operate as the optical alignment of the laser beam with respect to the optical cavity does not need to be mode-matched (Baer et al., 2002). Both instruments collected data with a $1 \mathrm{~Hz}$ sampling frequency. Particle phase emissions measurements were also made during experiments, but we reserve the presentation of those results for a future publication.

For gas measurements, the sample flow was diluted with zero air (i.e. $20.5 \% \mathrm{O}_{2}$ in $\mathrm{N}_{2}$ ) to enable simultaneous quantification of $\mathrm{N}_{2} \mathrm{O}$ and CO. During calibrations (Fig. 3) there was spectral broadening of the $\mathrm{CO}$ absorbance peak with smouldering combustion ( $\mathrm{CO}$ concentrations in excess of $10 \mathrm{ppm}$ ) which prevented the $\mathrm{N}_{2} \mathrm{O}$ absorbance peak from being quantified accurately. To keep the $\mathrm{CO}$ concentration below $10 \mathrm{ppm}$ and to prevent spectral broadening, a dilution ratio between 5.7 and 6.0 for flanking and backing fires and between 5.9 and 10.7 for heading fires was used. Heading fires required the initial dilution ratio to be increased during the experiment, which is why these dilution ratios are greater than those for flanking and backing fires.

Calibration of the $\mathrm{N}_{2} \mathrm{O} / \mathrm{CO}$ instrument (before and after experiments) against bottled $\mathrm{CO}$ gas gave coefficients of determination of 0.9993 and 0.9996 based on a linear fit between the measured $\mathrm{CO}$ concentration and the concentration provided by the calibration system, with slopes of these linear fits being 0.94 and 1.07. Overall, the calibrations performed before and after experiments confirmed the linear response and accuracy of the off-axis ICOS technique.

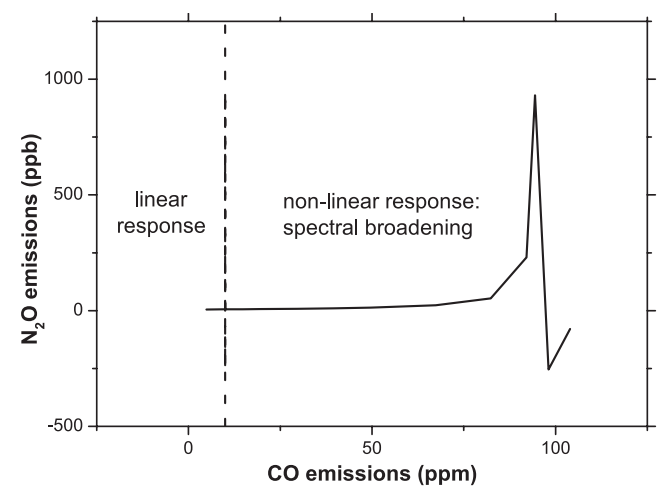

Figure 3. A graph of the interaction between $\mathrm{N}_{2} \mathrm{O}$ and $\mathrm{CO}$ emissions measurements during routine calibrations which necessitated the use of a dilution system.

\subsection{Data analysis}

\subsubsection{Calculation of emissions factors}

Emissions ratios are widely used in biomass burning research to rectify the problems associated with plume sampling in environments subject to variable levels of dilution (Le Canut et al., 1996) and as such are used as an input to enable the calculation of emissions factors. An emissions ratio (ER) is calculated via the following equation (Levine and Cofer III, 2000):

$\mathrm{ER}=\frac{\Delta X}{\Delta \text { reference gas }}$,

where $X$ is the gas of interest, the reference gas is usually either $\mathrm{CO}$ or $\mathrm{CO}_{2}$ (although $\mathrm{CH}_{4}$ is sometimes used), and $\Delta$ is the excess mixing ratio which denotes that the smoke-free ambient concentration is subtracted from the plume concentration (i.e. $\Delta X=X_{\text {plume }}-X_{\text {ambient }}$ ).

The selection of the reference gas is based on the quality of a linear fit between excess mixing ratios of the gas of interest ( $y$ axis) and the reference gas ( $x$ axis). The slope of the resulting linear fit therefore provides another method for quantifying an emissions ratio. Figure 4 shows correlation plots for incomplete combustion products using either $\mathrm{CO}_{2}, \mathrm{CO}$, or $\mathrm{CH}_{4}$ as a reference gas. The best linear fit was obtained for $\mathrm{CH}_{4}$ using $\mathrm{CO}$ as a reference gas $\left(R^{2}=0.942\right)$ and by us- 

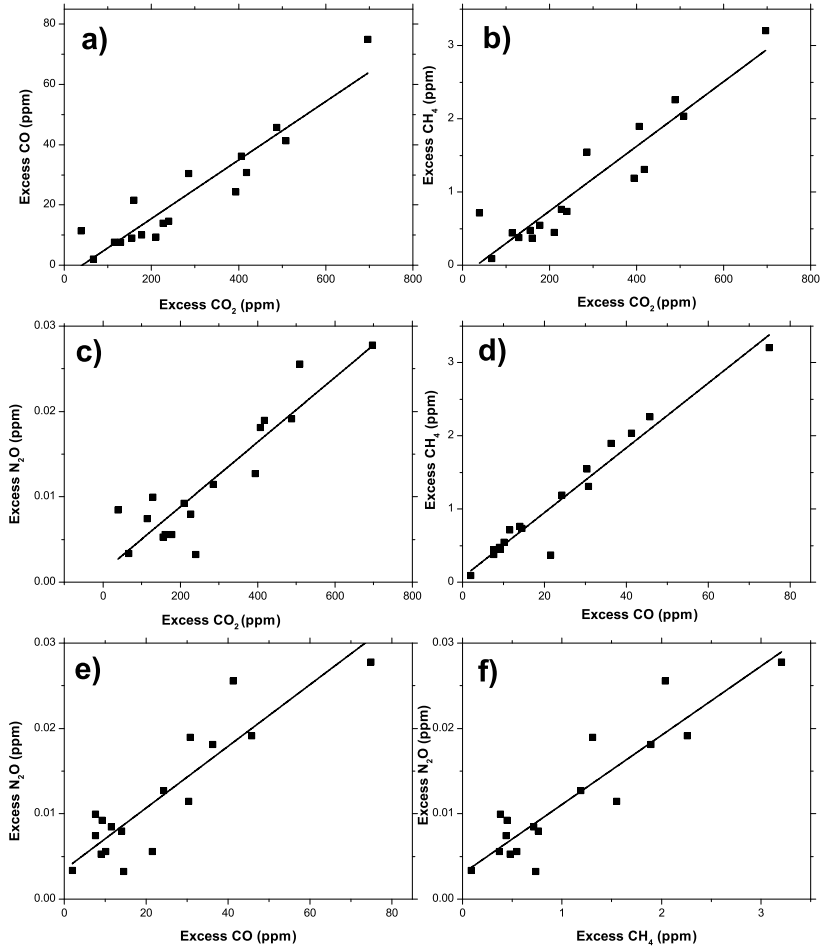

Figure 4. Linear fits of excess mixing ratios for all 18 experimental fires (not corrected for the overall dilution ratio) using either $\mathrm{CO}_{2}, \mathrm{CO}$ or $\mathrm{CH}_{4}$ as a reference gas: (a) $\mathrm{CO}$ plotted against $\mathrm{CO}_{2} \quad\left(R^{2}=0.872, \mathrm{CO}=-3.99+0.097 \mathrm{CO}_{2}\right)$; (b) $\mathrm{CH}_{4}$ plotted against $\mathrm{CO}_{2} \quad\left(R^{2}=0.871, \mathrm{CH}_{4}=-0.14\right.$ $\left.+0.0044 \mathrm{CO}_{2}\right)$; (c) $\mathrm{N}_{2} \mathrm{O}$ plotted against $\mathrm{CO}_{2} \quad\left(R^{2}=0.811\right.$, $\left.\mathrm{N}_{2} \mathrm{O}=0.0012+3.79 \times 10^{-5} \mathrm{CO}_{2}\right) ;\left(\right.$ d) $\mathrm{CH}_{4}$ plotted against $\mathrm{CO}$ $\left(R^{2}=0.942, \mathrm{CH}_{4}=-0.066+0.044 \mathrm{CO}\right) ;\left(\right.$ e) $\mathrm{N}_{2} \mathrm{O}$ plotted against $\mathrm{CO} \quad\left(R^{2}=0.788, \quad \mathrm{~N}_{2} \mathrm{O}=0.0035+3.61 \times 10^{-4} \mathrm{CO}\right) ;$ (f) $\mathrm{N}_{2} \mathrm{O}$ plotted against $\mathrm{CH}_{4}\left(R^{2}=0.822, \mathrm{~N}_{2} \mathrm{O}=0.0030+0.0081 \mathrm{CH}_{4}\right)$.

ing $\mathrm{CH}_{4}$ as a reference gas for $\mathrm{N}_{2} \mathrm{O}$ emissions $\left(R^{2}=0.822\right)$. Overall, the degree of fit with all three reference gases was similar, so $\mathrm{CO}_{2}$ was used as a reference gas since it is the dominant carbon-containing compound in the plume and it is also a relatively simple gas to measure (Levine and Cofer III, 2000).

A carbon mass balance approach developed by Radke et al. (1988), and applied (for example) by Lobert et al. (1990) and Hurst et al. (1994a, b), was used to calculate emissions factors for different carbon- and nitrogen-based pollutants on a per unit element burnt basis. Calculating emissions factors this way enables the fraction of carbon (or nitrogen) emitted from different chemical compounds containing that element to be quantified. Using $\mathrm{CO}_{2}$ as a reference gas for all carbon containing species, the emissions factor for carbon dioxide $\left(\mathrm{EF}_{\mathrm{CO}_{2}}\right)$ is given by

$\mathrm{EF}_{\mathrm{CO}_{2}}=\frac{\frac{\sum C_{\text {emit }}}{C_{\text {fuel }}}}{1+\frac{\Delta \mathrm{CO}_{2}}{\Delta \mathrm{CO}_{2}}+\frac{\Delta \mathrm{CH}_{4}}{\Delta \mathrm{CO}_{2}}+\frac{\Delta \sum \mathrm{NMHC}_{2}}{\Delta \mathrm{CO}_{2}}+\frac{\Delta \mathrm{PC}}{\Delta \mathrm{CO}_{2}}}$, where $C_{\text {emit }}$ is the mass of carbon emitted to the atmosphere, $C_{\text {fuel }}$ is the mass of fuel carbon burnt, NMHC represents the sum of all non-methane hydrocarbons and $\mathrm{PC}$ represents particulate carbon. NMHC have not been quantified in the current study; however, to complete the calculation of emissions factors in the above equation, an NMHC emissions factor of 0.0091 has been used based on the fire emissions work of Hurst et al. (1994a) in Australian savannas. Note that there are no published estimates of PC emissions ratios in Australian temperate forests so this term has been removed from the calculation of emissions factors. Removing PC emissions ratios from the calculation of emissions factors would have a very marginal impact on the final results with an upwards bias of $<1-2 \%$ being likely (Yokelson et al., 1999).

To calculate carbon-based emissions factors for compounds other than $\mathrm{CO}_{2}$ the following equation was used:

$\mathrm{EF}_{X}=\frac{\Delta X}{\Delta \mathrm{CO}_{2}} n \mathrm{EF}_{\mathrm{CO}_{2}}$,

where $n$ is the number of carbon atoms in the compound of interest.

By definition, the sum of all carbon-based emissions factors equals the fraction of burnt fuel carbon that is emitted to the atmosphere. This expression is given by

$\sum_{X} \mathrm{EF}_{X}=\frac{\sum C_{\text {emit }}}{C_{\text {fuel }}}$.

To estimate emissions factors for $\mathrm{N}_{2} \mathrm{O}$, the excess mixing ratio for $\mathrm{N}_{2} \mathrm{O}$ is substituted into the numerator of Eq. (3) and is then divided by the molar nitrogen-to-carbon ratio of the fuel to account for the fact that every mole of $\mathrm{N}_{2} \mathrm{O}$ has two moles of N. Performing this calculation makes nitrogenbased emissions factors independent of the nitrogen content of the fuel (Hurst et al., 1994b). Nitrogen-to-carbon ratios $(0.73 \%)$ were measured from un-burnt fuel samples, consisting of leaf, bark and twig components, using isotope ratio mass spectrometry.

Whilst reporting emissions factors on a per unit element burnt basis is common in inventory reporting, in atmospheric chemistry it is common to report emissions factors per unit of dry fuel consumed. The carbon mass balance method used to present emissions factors this way is discussed by Yokelson et al. (1999) and Paton-Walsh et al. (2014) and for carbon containing species is given by the following equation:

$\mathrm{EF}_{i}=F_{\mathrm{C}} \times 1000 \times \frac{\mathrm{MM}_{i}}{12} \times \frac{C_{i}}{C_{\mathrm{T}}}$,

where $\mathrm{EF}_{i}$ is the mass of compound $i$ emitted per kg of dry fuel consumed, $F_{\mathrm{C}}$ is the fractional fuel carbon content (measured before burning: 0.516 ), 1000 is a units conversion factor $\left(1000 \mathrm{~g} \mathrm{~kg}^{-1}\right), \mathrm{MM}_{i}$ is the molecular mass of species $i, 12$ is the atomic mass of carbon, $C_{i} / C_{\mathrm{T}}$ is the number of moles of species $i$ emitted divided by the total number of moles of carbon emitted. 
When using $\mathrm{CO}_{2}$ as a reference gas, $C_{i} / C_{T}$ is given by

$$
\frac{C_{i}}{C_{\mathrm{T}}}=\frac{\frac{\Delta C_{i}}{\Delta \mathrm{CO}_{2}}}{\sum_{j} \mathrm{NC}_{j} \frac{\Delta C_{j}}{\Delta \mathrm{CO}_{2}}},
$$

where $\Delta C_{i}$ and $\Delta C_{j}$ are the excess mixing ratios for species $i$ and $j$ and $\mathrm{NC}_{j}$ is the number of carbon atoms in species $j$.

To calculate $\mathrm{N}_{2} \mathrm{O}$ emissions factors per unit of dry fuel consumed, the following equation (based on Andreae and Merlet, 2001) was used:

$\mathrm{EF}_{\mathrm{N}_{2} \mathrm{O}}=\mathrm{ER}_{\mathrm{N}_{2} \mathrm{O} / \mathrm{CO}_{2}} \times \frac{\mathrm{MM}_{\mathrm{N}_{2} \mathrm{O}}}{\mathrm{MM}_{\mathrm{CO}_{2}}} \times \mathrm{EF}_{\mathrm{CO}_{2}}$.

This equation uses a molar emissions ratio for $\mathrm{N}_{2} \mathrm{O} / \mathrm{CO}_{2}$, the $\mathrm{CO}_{2}$ emissions factor and the respective molecular masses to calculate an emissions factor.

\subsubsection{Other calculations}

Time series data of excess mixing ratios was calculated by subtracting the diluted ambient readings for emissions before the test from the plume diluted concentrations, as the emissions from the fire only (and not ambient air) were of interest. Concentrations were then multiplied by the dilution ratio to enable undiluted plume concentrations to be calculated.

Emissions factors reported on a per unit dry fuel consumed basis were estimated (using Eq. 5 for carbon containing species and Eq. 7 for $\mathrm{N}_{2} \mathrm{O}$ ) separately for the flaming and smouldering combustion phases of each fire. Furthermore, plotting the results of Eqs. (5) and (7) vs. time enabled time series of emissions factors $\left(\mathrm{g} \mathrm{kg}^{-1}\right)$ to be calculated.

\subsubsection{Statistical analysis of data}

Multivariate analysis of covariance (MANCOVA) was performed to test for the statistical significance of fire spread mode (a categorical factor) and fine fuel moisture content (a numerical covariate) on the emissions factors measured. The one-way MANCOVA analysis involved testing hypotheses related to a single categorical variable and a single numerical covariate. The approach of having an explicit experimental design which facilitated the use of appropriate statistical methods was, in part, motivated by Meyer et al. (2012) who statistically examined relationships between vegetation type and the seasonality of burning on $\mathrm{CH}_{4}$ and $\mathrm{N}_{2} \mathrm{O}$ emissions factors from savanna fires in hummock and tussock open woodlands in the Northern Territory, Australia.

The statistical models fitted to the data were of the following form:

$$
Y_{i j k}=\underbrace{\mu}_{\text {Grand mean }}+\underbrace{\alpha_{i j}}_{\text {Treatment effect }}+\underbrace{\beta_{i j}}_{\text {Covariate effect }}+\underbrace{\epsilon_{i j k}}_{\text {Residual }},
$$

where $Y_{i j k}$ is the response (i.e. the emissions factor) for the $i$ th emissions species for the $j$ th fire spread mode and for the $k$ th replicate.
The null hypothesis $\left(H_{0}\right)$ being tested for the categorical variable (fire spread mode) was

$H_{0}: \mu_{i \mathrm{H}}=\mu_{i \mathrm{~F}}=\mu_{i \mathrm{~B}}$ for $\forall i$,

where $\mathrm{H}, \mathrm{F}$ and $\mathrm{B}$ denote the levels of the fire spread mode factor (i.e. heading, flanking and backing fires).

This hypothesis states that different fire spread modes (i.e. heading, backing and flanking) do not lead to significant differences in emissions for all species investigated (i.e. $\mathrm{CO}_{2}$, $\mathrm{CO}, \mathrm{CH}_{4}, \mathrm{~N}_{2} \mathrm{O}$ and residue carbon).

The alternative hypothesis $\left(H_{1}\right)$ being tested was that at least one of the $\mu_{i j}$ comparisons in Eq. (9) were concluded to differ.

The null hypothesis being tested for the covariate (fine fuel moisture content) was

$H_{0}: \beta_{i \mathrm{H}}=\beta_{i \mathrm{~F}}=\beta_{i \mathrm{~B}}$ for $\forall i$,

while the alternative hypothesis tested that at least one of the $\beta_{i j}$ slope comparisons in Eq. (10) were concluded to differ.

In addition, multivariate analysis of variance (MANOVA) was performed to test whether fire spread mode and combustion phase (i.e. flaming or smouldering combustion) had a statistically significant impact on emissions factors reported on a per unit dry fuel consumed basis. The statistical models fitted and hypotheses tested had the same structure as Eq. (8), except instead of having a single factor and a covariate, two categorical factors (i.e. fire spread mode and combustion phase) were fitted in this two-way MANOVA. All statistical tests were conducted using R v 3.03 and a significance level of $5 \%$ was used to determine statistical significance.

\section{Results}

\subsection{Fire behaviour}

Table 1 reports summary statistics from the fire experiments which shows that flanking and backing fires are quite similar in terms of their Byram fire line intensity (Byram, 1959), rate of spread and duration of smouldering combustion. Heading fires spread about 20 times faster and with approximately 20 times higher fire line intensity than flanking or backing fires. Furthermore, the duration of flaming combustion was about $75 \%$ less with heading fires and smouldering combustion was more than twice as long.

\subsection{Excess mixing ratios}

Time series data for the excess mixing ratios of $\mathrm{CO}_{2}, \mathrm{CO}$, $\mathrm{CH}_{4}$, and $\mathrm{N}_{2} \mathrm{O}$ are shown in Fig. 5. The two most striking aspects are the relative magnitudes of the emissions peaks, and also differences in the combustion duration for different fire spread modes. Heading fires produced very pronounced peaks during flaming combustion for all emissions species 

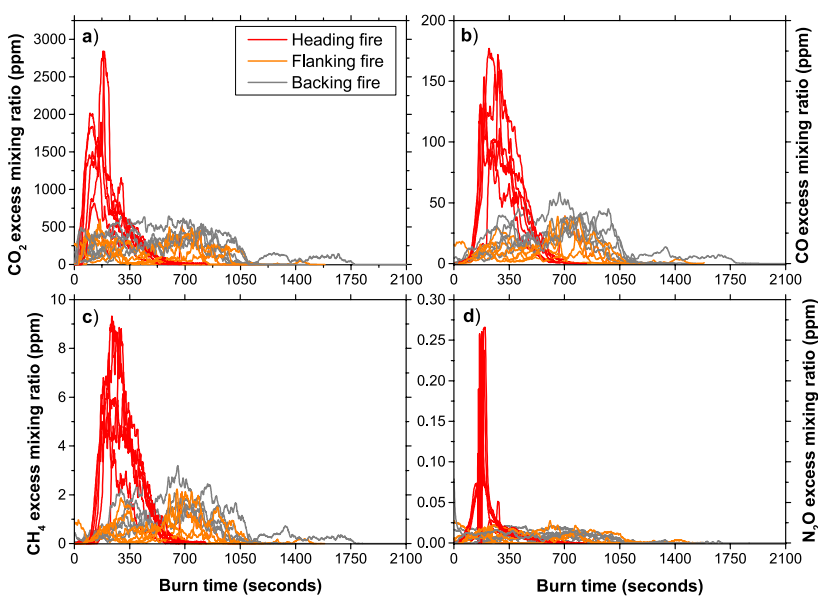

Figure 5. Time series of excess mixing ratios for different emissions species and three different fire spread modes: (a) $\mathrm{CO}_{2}$; (b) $\mathrm{CO}$; (c) $\mathrm{CH}_{4}$; (d) $\mathrm{N}_{2} \mathrm{O}$. Note that each line of a particular colour represents one experimental replicate.

considered, whereas flanking and backing fires exhibited less temporal variability in their emissions with less pronounced peaks. The temporal variability in emissions is very similar for flanking and backing fires.

\subsection{Modified combustion efficiency}

Figure 6 shows time series of MCE for the experimental fires. The rather rapid transition from high $(\sim 1)$ to low $(\sim 0.9)$ MCE values for heading fires (in the space of about $2 \mathrm{~min}$ for four of the six replicates) is apparent when nearly the whole fuel bed was involved in flaming and smouldering combustion. In contrast, backing fires show a linear reduction in MCE with respect to time and so do flanking fires; however, there is more variability in their MCE time series due to the fire not always propagating with a uniform flame front. Differences in combustion dynamics can also be observed from the bottom panel of Fig. 6. Flame-only combustion is the shortest phase and lasts for less than $1 \mathrm{~min}$ for all fire spread modes. Mixed combustion (i.e. flaming and smouldering) is the longest phase for flanking and backing fires and smouldering-only combustion is the longest phase for heading fires.

\subsection{Emissions factors: fire spread mode}

Emissions factors for carbon- and nitrogen-based species using the carbon mass balance approach show that between 63 and $74 \%$ of fuel carbon is emitted to the atmosphere as $\mathrm{CO}_{2}$, and about $5.7-13 \%$ is emitted as $\mathrm{CO}$ (Fig. 7a), 0.36-0.53\% as $\mathrm{CH}_{4}$ and $0.35-0.57 \%$ of fuel nitrogen as $\mathrm{N}_{2} \mathrm{O}$ (Fig. 7b). For heading fires, the $\mathrm{CO}_{2}$ emissions factor was about $17 \%$ greater than flanking fires and $9.5 \%$ higher than backing fires and $\mathrm{CO}$ emissions factors were about twice as high for heading fires than for the other two fire spread modes. The frac-

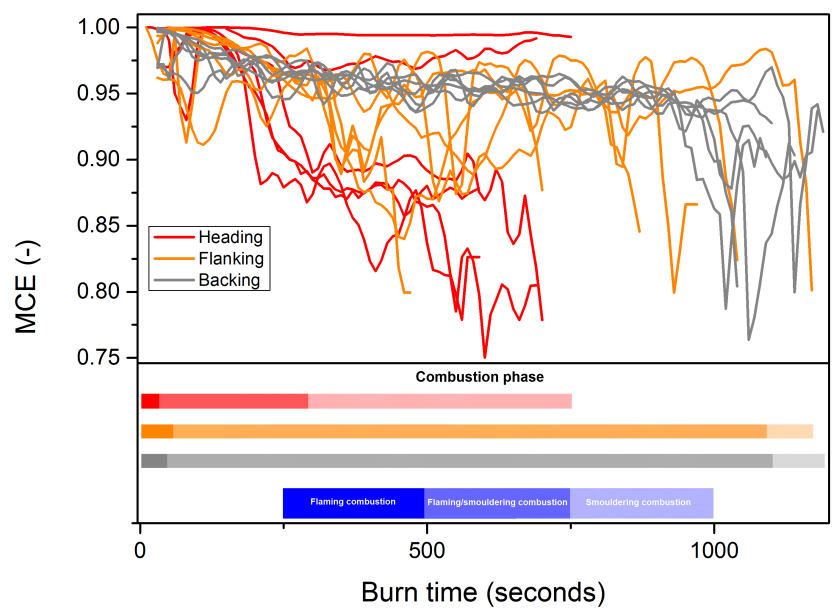

Figure 6. Time series of MCE for the experimental burns. The combustion phase for each fire spread mode is split into the duration of flaming, flaming and smouldering and smouldering combustion.

tion of un-consumed burnt carbon (fuel residue) ranges from $12 \%$ for heading fires and up to $30 \%$ for flanking fires. During some experiments, it was difficult to get flanking fires to propagate with a continuous flame front which offers an explanation for the greater production of combustion residue (due to patchiness) during these fires. Table 2 reports emissions factors for all four emissions species per unit dry fuel consumed.

Statistical testing of the results with MANCOVA indicated that fine fuel moisture content (i.e. the covariate) did not have an impact on emissions factors $(p=0.60)$; however, fire spread mode was a statistically significant factor $(p<0.0001)$. Fire spread mode had a statistically significant effect on $\mathrm{CO}_{2}(p<0.0001), \mathrm{CO}(p<0.0001)$ and carbon residue production $(p<0.0001)$ but did not have a statistically significant effect on $\mathrm{CH}_{4}(p=0.269)$ or $\mathrm{N}_{2} \mathrm{O}$ emissions $(p=0.261)$. Testing with pairwise comparisons showed that $\mathrm{CO}_{2}$ emissions factors for all paired combinations of fire spread mode (i.e. heading vs. backing, heading vs. flanking and flanking vs. backing) were statistically different ( $p<0.0001$ for all comparisons). For CO emissions, heading vs. backing and heading vs. flanking emissions factors were statistically different $(p<0.0001$ for all comparisons); however, flanking emissions factors were not statistically different to backing emissions factors $(p=0.962)$.

\subsection{Emissions factors: combustion phase}

As shown previously (see Fig. 7), emissions factors for different chemical species varied significantly with respect to fire spread mode. In addition, the different phases of combustion (e.g. flaming and smouldering) behave differently and potentially have different emissions profiles (Lee et al., 2010). Emissions factors (per unit of dry fuel consumed) were calculated separately for flaming and smoul- 
Table 2. Emissions factors ( \pm one standard deviation) for emissions species reported on a per unit of dry fuel consumed basis.

\begin{tabular}{lcccc}
\hline Data source & $\mathrm{CO}_{2}\left(\mathrm{~g} \mathrm{~kg}^{-1}\right)$ & $\mathrm{CO}\left(\mathrm{g} \mathrm{kg}^{-1}\right)$ & $\mathrm{CH}_{4}\left(\mathrm{~g} \mathrm{~kg}^{-1}\right)$ & $\mathrm{N}_{2} \mathrm{O}\left(\mathrm{g} \mathrm{kg}^{-1}\right)$ \\
\hline Heading fires (this study) & $1594 \pm 46$ & $172 \pm 30$ & $4.2 \pm 0.5$ & $0.089 \pm 0.043$ \\
Flanking fires (this study) & $1709 \pm 18$ & $98 \pm 11$ & $4.3 \pm 2.7$ & $0.117 \pm 0.071$ \\
Backing fires (this study) & $1716 \pm 14$ & $95 \pm 9$ & $3.3 \pm 1.3$ & $0.064 \pm 0.031$ \\
Andreae and Merlet (2001) & $1569 \pm 131$ & $107 \pm 37$ & $4.7 \pm 1.9$ & $0.26 \pm 0.07$ \\
Akagi et al. (2011) & $1637 \pm 71$ & $89 \pm 32$ & $3.9 \pm 2.4$ & $0.16 \pm 0.21$ \\
Paton-Walsh et al. (2014) & $1620 \pm 30$ & $118 \pm 16$ & $3.5 \pm 1.1$ & $0.15 \pm 0.09$ \\
\hline
\end{tabular}
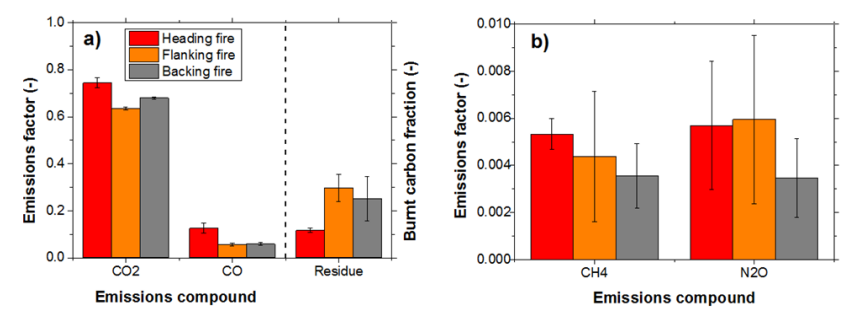

Figure 7. Carbon and nitrogen based emissions factors (per unit of carbon or nitrogen burnt) and burnt carbon residue fractions from the experimental burns: (a) $\mathrm{CO}_{2}, \mathrm{CO}$ and residue carbon emissions factors; (b) $\mathrm{CH}_{4}$ and $\mathrm{N}_{2} \mathrm{O}$ emissions factors.

dering phases for the 18 experimental fires (Fig. 8). In this paragraph we discuss the numerical trends found, whilst the next paragraph discusses testing of our results for statistical significance. Numerically, the results confirm that both $\mathrm{CO}$ and $\mathrm{CH}_{4}$ emissions factors were substantially increased during smouldering combustion. $\mathrm{CO}$ emissions factors ranged from 72 to $102 \mathrm{~g} \mathrm{~kg}^{-1}$ during flaming combustion and ranged from 189 to $221 \mathrm{~g} \mathrm{~kg}^{-1}$ during smouldering combustion. $\mathrm{CH}_{4}$ emissions factors ranged from 2.4 to $3.8 \mathrm{~g} \mathrm{~kg}^{-1}$ during flaming combustion and 5.0 to $10.5 \mathrm{~g} \mathrm{~kg}^{-1}$ during smouldering combustion. With more carbon being emitted as either $\mathrm{CO}$ or $\mathrm{CH}_{4}$ during smouldering combustion, this led to decreases in the $\mathrm{CO}_{2}$ emissions factor, with $\mathrm{CO}_{2}$ emissions factors ranging from 1705 to $1750 \mathrm{~g} \mathrm{~kg}^{-1}$ during flaming combustion and from 1515 to $1550 \mathrm{~g} \mathrm{~kg}^{-1}$ during smouldering combustion. Numerically, $\mathrm{N}_{2} \mathrm{O}$ emissions factors did not increase during smouldering combustion for heading fires but did increase for both backing and flanking fires.

The MANOVA analysis confirms that combustion phase $(p<0.0001)$ had a statistically significant impact on emissions factors (reported per unit of dry fuel consumed) and so did fire spread mode, but only for the heading fire vs. flanking fire comparison $(p=0.04) . \mathrm{CO}_{2}$ emissions factors were lower during smouldering combustion $(p<0.0001)$ whilst $\mathrm{CO}$ emissions factors were increased $(p<0.0001)$. $\mathrm{CH}_{4}$ emissions factors did not exhibit statistically significant differences with respect to combustion phase $(p=0.12)$, but $\mathrm{N}_{2} \mathrm{O}$ emissions factors did $(p=0.04)$. Whilst the nonsignificant result for $\mathrm{CH}_{4}$ may appear to contradict the trends discussed in the previous paragraph, the $\mathrm{CH}_{4}$ results are more
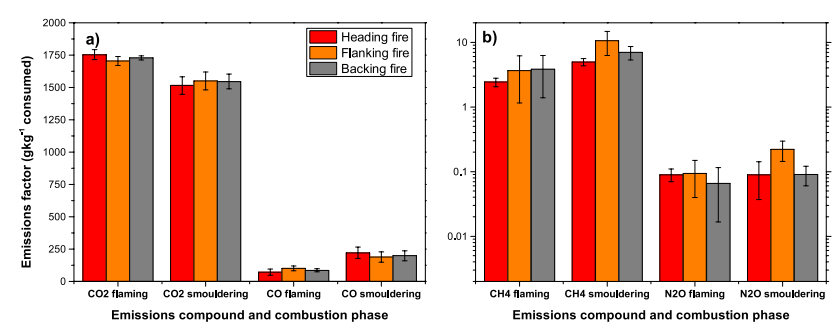

Figure 8. Carbon and nitrogen based emissions factors (per unit of dry fuel consumed) for different combustion phases within the experimental burns: (a) $\mathrm{CO}_{2}$ and $\mathrm{CO}$ emissions factors for flaming and smouldering combustion; (b) $\mathrm{CH}_{4}$ and $\mathrm{N}_{2} \mathrm{O}$ emissions factors for flaming and smouldering combustion.

variable which prevents a statistically significant result from being found. Furthermore, $\mathrm{N}_{2} \mathrm{O}$ emissions factors exhibited a relationship with fire spread mode $\left(p=6.5 \times 10^{-3}\right)$ with heading fires producing less $\mathrm{N}_{2} \mathrm{O}$ than flanking or backing fires.

\subsection{Emissions factors: time resolved}

Time-resolved emissions factors (on a per dry fuel consumed basis) were calculated and are shown in Fig. 9. Presenting emissions factors in a temporal fashion enables the effects of fire spread mode and combustion phase to be identified simultaneously. This graph shows that the $\mathrm{CO}_{2}$ emissions factor peaks early in the burn during flaming combustion with a pronounced decrease (and a commensurate increase in $\mathrm{CO}$ ) after the passage of the flame front through the fuel bed. $\mathrm{CH}_{4}$ and $\mathrm{CO}$ emissions factors are quite low during flaming combustion, but increase significantly once smouldering combustion starts to dominate. As we discuss in Sect. 4.5, the rapid transition from short-lived flame-only combustion to lengthy predominantly smouldering combustion is an inherent property of heading fires leading to increased $\mathrm{CO}$ emissions. $\mathrm{N}_{2} \mathrm{O}$ emissions show a significant contribution from both flaming and smouldering combustion. 

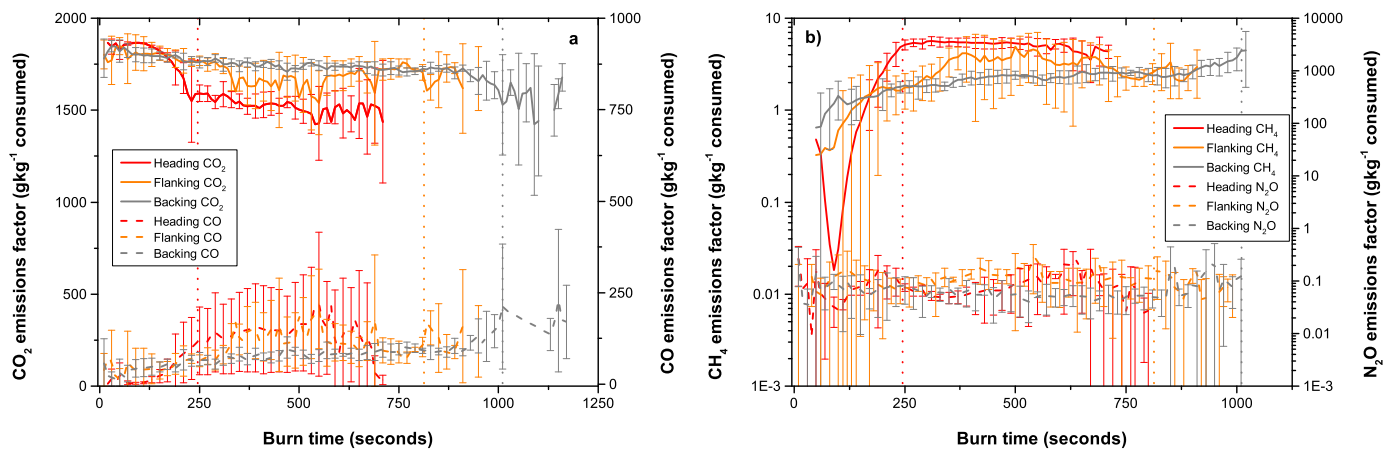

Figure 9. Time-resolved emissions factors for the trace gas emissions species measured during the experimental burns. (a) Time-resolved $\mathrm{CO}_{2}$ and $\mathrm{CO}$ emissions factors. (b) Time-resolved $\mathrm{CH}_{4}$ and $\mathrm{N}_{2} \mathrm{O}$ emissions factors. Coloured vertical and dotted bars represent the median end time for predominantly flaming combustion for each fire spread mode.

\section{Discussion}

\subsection{Equivalence of emissions factor reporting}

In this section, we discuss a comparison between the two methods for reporting emissions factors which are both based on a carbon mass balance approach (see Sect. 2.4.1). As such, we switch interchangeably between reporting on a per unit element burnt basis (i.e. either fuel carbon or nitrogen) or a per unit dry fuel consumed basis. For our purposes, we define "burnt" as fuel that has been thermally altered as a result of exposure to fire and either emitted to the atmosphere or left in the post-fire residue. We define "consumed" as that component of the fuel that is emitted to the atmosphere as a result of exposure to fire. The relevant equation number or associated units are provided to make it clear which emissions factor reporting method we are using.

Comparison of the emissions factors reported per unit element burnt (Fig. 7) with those reported per unit of dry fuel consumed (Table 2) led to the apparently anomalous conclusion that $\mathrm{CO}_{2}$ emissions factors are greater for flanking and backing fires; a result which directly contradicts those reported in Fig. 7. To properly resolve this apparent inconsistency, it is important to realise that emissions factors calculated using either Eqs. (2) or (5) are only estimates and there are several sources of error. A source of error common to both Eqs. (2) and (5) arises because it is not possible to measure all the carbon compounds present in the smoke plume.

If carbon-based emissions factors were to be calculated using only $\mathrm{CO}_{2}, \mathrm{CO}$ and $\mathrm{CH}_{4}$ (which is a common approach), the total amount of carbon emitted would be underestimated by $1-2 \%$ due to omitting NMHC and by a further 1-2\% for neglecting PC (Yokelson et al., 1999). The implication of not measuring all carbon emitted in the plume is that the emissions factor would be overestimated. Further sources of error include estimating the carbon fraction deposited in ash (Eq. 2) and estimating the fuel carbon content before burning takes place (Eq. 5). In atmospheric chemistry studies it is common to assume a fuel carbon content of $50 \%$ (PatonWalsh et al., 2014; Yokelson et al., 1999) whilst Hurst et al. (1996) assumed that $6 \%$ of fuel carbon was deposited in ash. In this study, both the fuel carbon fraction before burning and the fraction of carbon deposited in ash were measured, meaning that these sources of error have been eliminated from the analysis.

A further source of error which has received limited discussion in the literature relates to the equivalence of the methods described in Eqs. (2) and (5). In particular, the calculation of total emissions from a fire should not depend on which metric is used to calculate emissions factors. The method described in Eq. (2) is commonly used in inventory reporting and is a well-established methodology. In contrast, applying Eq. (5) to estimate total emissions would involve multiplying the area burnt, fuel load, combustion factor and emissions factor and would not report the same result as Eq. (2). The reason for this discrepancy is that the method described in Eq. (5) does not explicitly consider the fraction of total fuel carbon emitted to the atmosphere. Instead, this method implicitly assumes that all fuel carbon is emitted to the atmosphere.

Making the assumption that all fuel carbon is emitted to the atmosphere might be acceptable in the head fire of a high intensity wildfire; however, in the current work a significant fraction of burnt fuel carbon (12-30\%) is contained in the post-fire residue and furthermore displays a trend with respect to fire spread mode. As a result, in burning conditions representative of prescribed burning it is not acceptable to assume that all fuel carbon is emitted to the atmosphere and instead this fraction should be estimated, as recommended by Andreae and Merlet (2001) and as done in the current work. Multiplication of Eq. (5) by $\sum C_{\text {emit }} / C_{\text {fuel }}$ would enable the per unit dry fuel consumed method of reporting emissions factors to report the same total emissions as the per unit element burnt method. Performing this correction leads to the correct trend in $\mathrm{CO}_{2}$ emissions factors with respect to fire spread mode, with heading fires $\left(1407 \mathrm{~g} \mathrm{~kg}^{-1}\right)$ 
emitting more $\mathrm{CO}_{2}$ than flanking $\left(1200 \mathrm{~g} \mathrm{~kg}^{-1}\right)$ or backing fires $\left(1284 \mathrm{~g} \mathrm{~kg}^{-1}\right)$.

\subsection{Comparison with previous field and laboratory measurements}

This emissions study was performed in a combustion wind tunnel facility with comparison of the results obtained with those acquired in the field constituting a very important validation exercise. Recently Volkova et al. (2014) explored the relationship of burning on the carbon and greenhouse gas emissions from subsequent wildfire in temperate forest in Victoria, Australia. Measurements of $\mathrm{CH}_{4}$ and $\mathrm{N}_{2} \mathrm{O}$ emissions factors over a very wide $\mathrm{MCE}$ range (0.7-1) were made during fuel burning. The laboratory-derived $\mathrm{CH}_{4}$ and $\mathrm{N}_{2} \mathrm{O}$ emissions factors are in very good agreement with those measured by Volkova et al. (2014) who measured $\mathrm{CH}_{4}$ emissions factors (reported per unit element burnt) between 0.5 and $1.5 \%$ and $\mathrm{N}_{2} \mathrm{O}$ emissions factors between 0.4 and $1 \%$ over the MCE range relevant to the laboratory measurements (0.82-0.93).

Another valuable source of data for comparison is the data set of Paton-Walsh et al. (2014) who recently measured trace gas emissions factors with an FTIR system during prescribed fires in temperate forests in New South Wales, Australia. Our $\mathrm{CO}_{2}$ emissions factors (reported per unit of dry fuel consumed) are slightly smaller for heading fires $(\sim 1.5 \%)$ and are larger for flanking $(\sim 5 \%)$ and backing fires $(\sim 6 \%)$ compared to Paton-Walsh et al. (2014). Keeping in mind that emissions sampling from an active fire front will involve contributions from different fire spread modes (especially heading and flanking) makes the overall $\mathrm{CO}_{2}$ emissions profile from our measurements consistent with those reported by Paton-Walsh et al. (2014).

Our CO emissions factors (reported per unit of dry fuel consumed) are significantly higher for heading fires $(\sim 45 \%)$ due to significant smouldering after the progression of the flame front (see Fig. 8), but are lower for flanking ( 17\%) and backing fires $(\sim 19 \%)$. Our $\mathrm{CH}_{4}$ emissions factors (reported per unit of dry fuel consumed) are higher for heading $(20 \%)$ and flanking $(\sim 23 \%)$ fires but are slightly lower for backing $(\sim 6 \%)$ fires. Increases in our $\mathrm{CH}_{4}$ and $\mathrm{CO}$ emissions factors are consistent with sampling at a lower MCE in the combustion wind tunnel compared to the results of PatonWalsh et al. (2014). Our MCE range was 0.82-0.93, whereas the recommended emissions factors reported by Paton-Walsh et al. (2014) are based on an MCE average of 0.90. In contrast, our $\mathrm{N}_{2} \mathrm{O}$ emissions factors (reported per unit of dry fuel consumed) are lower for heading ( $\sim 41 \%)$, flanking ( $22 \%)$ and backing $(\sim 57 \%)$ compared to Paton-Walsh et al. (2014).

The only other published estimates of greenhouse gas emissions from temperate forest fires in Australia are those of Hurst et al. (1996) who measured $\mathrm{CO}_{2}, \mathrm{CO}$ and $\mathrm{CH}_{4}$ emissions factors for two wildfires in the Sydney region in February 1991, another wildfire in January 1994 and also a pre- scribed fire in March 1994. Averaged over four fires, they measured emissions factors (reported per unit element burnt) of $85 \%$ for $\mathrm{CO}_{2}, 9.1 \%$ for $\mathrm{CO}$ and $0.54 \%$ for $\mathrm{CH}_{4}$. They did not measure fuel consumption; however, the production of ash was assumed to be $6 \%$ of total fuel carbon. As seen from Fig. 7, the post-burn residue fraction in our study was much larger than that reported by Hurst et al. (1996), which places an upper limit on how much fuel carbon can be released as $\mathrm{CO}_{2}$. As a result, $\mathrm{CO}_{2}$ emissions factors measured by Hurst et al. (1996) are substantially higher than those we measured; however our range of $\mathrm{CO}$ emissions factors were similar to those reported by Hurst et al. (1996). $\mathrm{CH}_{4}$ emissions factors for heading fires were very similar in magnitude to those reported by Hurst et al. (1996) with $\mathrm{CH}_{4}$ emissions factors from flanking and backing fires being slightly less than those from heading fires.

Apart from emissions studies performed in the field in Australia, two studies from African savannas have explored the relationship between fire spread mode and emissions factors. Keene et al. (2006) collected vegetation from the savanna region in southern Africa and examined the relationship between fire spread mode (heading, backing and mixed (i.e. flanking) fires) and emissions of trace gases (e.g. $\mathrm{CO}_{2}$ and $\mathrm{CO}$ plus other species) and particulates with a burning table apparatus connected to a stack for sampling. Our MCE values varied only by a few percent with three different fire spread modes which is in agreement with the findings of Keene et al. (2006) for grass fires with a moisture content less than $20 \%$. Furthermore, we found that heading fires exhibited the lowest MCE (86.1\% in our study vs. $93.1 \%$ in Keene et al., 2006), and flanking and backing fires exhibited a slightly higher MCE (90.1 and 88.3\% in our study and 95.6 and $94.8 \%$ in Keene et al., 2006). Although not calculated in their study, the Keene et al. (2006) $\mathrm{CO}_{2}$ emissions factor (expressed per unit of carbon burnt) would only have varied by about $3 \%$ with the different fire spread modes due to having a very high fraction of carbon emitted to the atmosphere (>95\% for all three fire spread modes). This can be contrasted with our study where the fraction of carbon emitted to the atmosphere varied by approximately $18 \%$; even though all the fuel was burnt (see Fig. 7a). It is for this reason that there were statistically significant differences in our $\mathrm{CO}_{2}$ and $\mathrm{CO}$ emissions factors with respect to fire spread mode, even though, like Keene et al. (2006), our MCE values varied little.

In addition, Wooster et al. (2011) measured trace gas emissions factors in southern African savannas with an open-path FTIR system with results reported for heading and backing fires and also during the residual smouldering combustion (RSC) phase. Table 3 compares our emissions factors with those of Wooster et al. (2011) without correcting our results for the $\sum C_{\text {emit }} / C_{\text {fuel }}$ term (as recommended in Sect. 4.2) as this is usual practice in atmospheric chemistry. Consistent with the results of Wooster et al. (2011), our emissions factors increased for $\mathrm{CO}_{2}(\sim 8 \%)$ and decreased for both 
Table 3. Comparison of emissions factors with those of Wooster et al. (2011) for different fire spread modes and for residual smouldering combustion.

\begin{tabular}{lllrr}
\hline & & & \multicolumn{2}{c}{$\mathrm{EF}\left(\mathrm{g} \mathrm{kg}^{-1}\right)$} \\
\cline { 4 - 5 } Compound & Fire spread mode & Combustion phase & This study & Wooster et al. (2011) \\
\hline $\mathrm{CO}_{2}$ & Heading & Fire averaged & 1594 & 1674 \\
$\mathrm{CO}_{2}$ & Backing & Fire averaged & 1716 & 1692 \\
$\mathrm{CO}_{2}$ & Heading & Smouldering combustion & 1515 & - \\
$\mathrm{CO}_{2}$ & Backing & Smouldering combustion & 1546 & - \\
$\mathrm{CO}$ & N/A & RSC & - & 1600 \\
$\mathrm{CO}$ & Heading & Fire averaged & 172 & 97 \\
$\mathrm{CO}$ & Backing & Fire averaged & 95 & 85 \\
$\mathrm{CO}$ & Heading & Smouldering combustion & 221 & - \\
$\mathrm{CO}$ & Backing & Smouldering combustion & 198 & - \\
$\mathrm{CO}$ & N/A & RSC & - & 137 \\
$\mathrm{CH}$ & Heading & Fire averaged & 4.2 & 2.5 \\
$\mathrm{CH}_{4}$ & Backing & Fire averaged & 3.3 & 1.9 \\
$\mathrm{CH}_{4}$ & Heading & Smouldering combustion & 5.0 & - \\
$\mathrm{CH}_{4}$ & Backing & Smouldering combustion & 7.0 & - \\
$\mathrm{CH}_{4}$ & N/A & RSC & - & 5.2 \\
\hline
\end{tabular}

$\mathrm{CO}(\sim 45 \%)$ and $\mathrm{CH}_{4}(\sim 21 \%)$ for backing fires relative to heading fires. Compared to the results of Wooster et al. (2011), in our study backing fires caused the same percentage reduction in emissions factors for $\mathrm{CH}_{4}$, larger increases for $\mathrm{CO}_{2}(\sim 1 \%$ in Wooster et al., 2011) and larger decreases for CO ( $\sim 12 \%$ in Wooster et al., 2011). During smouldering combustion in our study (averaged for heading and backing fires), there were decreases in $\mathrm{CO}_{2}$ emissions factors $(\sim 7 \%)$ and pronounced increases for $\mathrm{CO}(\sim 57 \%)$ and $\mathrm{CH}_{4}$ $(\sim 60 \%)$. The changes in $\mathrm{CO}_{2}$ and $\mathrm{CO}$ emissions factors during smouldering combustion were very similar to those in the study of Wooster et al. (2011) (i.e. $\sim 5$ and $\sim 51 \%$ respectively) although they observed more pronounced increases in $\mathrm{CH}_{4}$ emissions factors $(\sim 138 \%)$ during RSC measurements.

Therefore, based on comparison of our results with four field sampling studies (three in Australia and one in southern Africa) and another laboratory study suggests that the design of the CSIRO Pyrotron has successfully captured the combustion and emissions dynamics that typically occur under field-burning conditions, including field burning studies where emissions from different fire spread modes were sampled.

\subsection{A comment on $\mathrm{N}_{2} \mathrm{O}$ emissions production}

As highlighted by van Leeuwen et al. (2013), exploring the temporal variability of emissions factors from biomass burning is an important consideration but is rarely undertaken. Despite reports in the literature of $\mathrm{N}_{2} \mathrm{O}$ emissions factors being dominant in flaming combustion (Lobert et al., 1990; Urbanski, 2013), there is strong evidence from Fig. 9 of contributions to $\mathrm{N}_{2} \mathrm{O}$ emissions from both flaming and smoulder- ing combustion. This fact is evident from Fig. $9 \mathrm{~b}$ by looking at the limited temporal variability in the $\mathrm{N}_{2} \mathrm{O}$ emissions factor (with respect to time) compared to other emissions species. Clearly further measurements and modelling work is required to develop a mechanistic understanding of $\mathrm{N}_{2} \mathrm{O}$ emissions production from fire.

\subsection{Implications for carbon accounting and sequestration}

The results from this study have implications for both the mitigation of greenhouse gas emissions from fire and also carbon accounting methods which we discuss with reference to prescribed burning in Victoria. The Royal Commission into the 2009 bushfires in Victoria recommended that $5 \%$ of Victoria's public land (approximately $390000 \mathrm{ha}$ ) should be burnt by prescribed fires each year to reduce the risk of bushfires (Teague et al., 2010). Using state-based and country-specific data from Australia's National Inventory System (Commonwealth of Australia, 2014), it is estimated that 5630 gigagrams $(\mathrm{Gg})$ of $\mathrm{CO}_{2}$ equivalent $\left(\mathrm{CO}_{2}\right.$-e $)$ emissions would be emitted from the burning of 390000 ha. Using the emissions and combustion factors derived from our experimental study (as an estimate of prescribed burning emissions and combustion factors) and keeping all other inputs fixed yields estimates of $5640 \mathrm{Gg}$ of $\mathrm{CO}_{2}$-e emissions if all the area is burnt by heading fire, $4200 \mathrm{Gg} \mathrm{CO}_{2}$-e if burnt by flanking fire and $4990 \mathrm{Gg} \mathrm{CO}_{2}$-e if burnt as a backing fire. Whilst it would not be possible to apply a single fire spread mode to a forested landscape in a prescribed fire situation, ignition patterns are practised in Victoria which enable a single fire spread mode to predominate (Tolhurst and Cheney, 1999), such as the three investigated in this study. 
This calculation suggests that the preferential application of flanking fires over heading fires during prescribed burning operations would save approximately $1280 \mathrm{Gg}$ of $\mathrm{CO}_{2}$ emissions with $420 \mathrm{Gg}$ being saved with backing fires. In addition, the application of flanking fires would leave an extra $265 \mathrm{Gg}$ of carbon as a post-fire combustion residue (compared to heading fires), and backing fires would leave an extra $250 \mathrm{Gg}$, preventing further carbon emissions to the atmosphere. A further benefit to the application of non-heading fires during prescribed burning would be a reduction in $\mathrm{CO}$ emissions, which are implicated in respiratory health effects, with flanking fires emitting $330 \mathrm{Gg}$ less $\mathrm{CO}$ (compared to heading fires) and backing fires emitting $290 \mathrm{Gg}$ less.

In addition, the results have implications for carbon accounting methods considering that Australia's National Inventory System does not currently discriminate between types of fire other than whether they are prescribed or wild. Given that, compared with heading fires, $\mathrm{CO}_{2}$-e emissions are about $26 \%$ lower for flanking fires and $11 \%$ lower for backing fires, there is potentially scope for more accurate greenhouse inventory reporting by taking into account the mode of fire spread. It should be noted that these calculations are indicative only, as they consider only a narrow range of burning conditions (wind speed, moisture content, etc). Real prescribed fires will be subject to wider variations in topography, vegetation and meteorology and thus a wider range of potential behaviours.

\subsection{Potential sampling biases}

Emissions sampling was conducted at a single fixed height above the wind tunnel floor for all experiments (see Sect. 2.1). As a result, if the plumes from the different combustion phases during an experiment were stratified and not adequately mixed, there is the possibility that weakly lofted smouldering combustion products (Christian et al., 2007; Wooster et al., 2011) from flanking and backing fires and strongly lofted flaming combustion products from heading fires were inadequately sampled. The former case would lead to underestimates of smouldering combustion products (i.e. for $\mathrm{CO}$ and $\mathrm{CH}_{4}$ ) and the latter would lead to underestimates of flaming combustion products. These would be observed as inconsistent MCE trends with respect to the temporal progression of the combustion phases, such as low MCEs for flaming fires and high MCEs for smouldering fires. To explore the potential of these biases in our results, we now consider the observed trends in MCE values in regard to fire behaviour.

Figure 10 displays the relationship between MCE and the percentage of the combusting fraction of the fuel bed undergoing smouldering combustion. For all three fire spread modes, a non-linear relationship between MCE and the percentage of smouldering combustion area is observed. The degree of correlation (determined from Spearman's rank correlation co-efficient) is strong with $\rho$ values of $-0.71,-0.75$

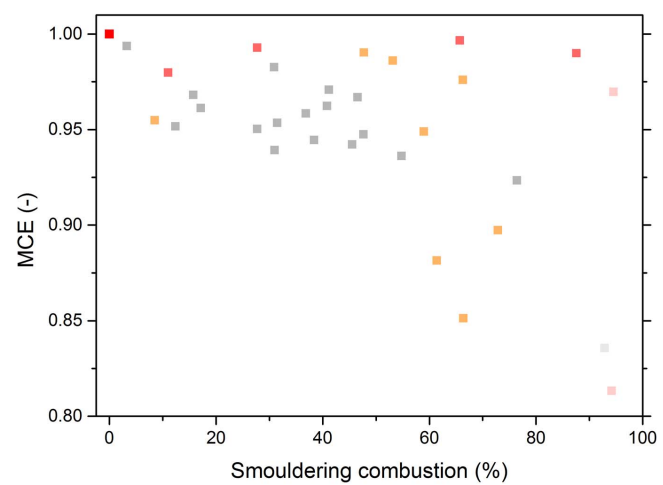

Figure 10. A scatter plot of MCE vs. the percentage area of the combusting fuel bed undergoing smouldering combustion. The same colour gradation scheme from Fig. 6 is used to denote different combustion phases. The first data point is nearly coincidental (i.e. MCE approximately 1) for all three fire spread modes, which is why only one symbol is visible.

and -0.65 being observed for heading, flanking and backing fires, respectively. When flame-only combustion is occurring, the MCE is very close to 1 , indicating almost all carbon is emitted as $\mathrm{CO}_{2}$ and suggesting that we are successfully sampling flaming combustion products from this phase. As each fire progresses and the percentage area of smouldering combustion increases, the MCE reduces accordingly. When combustion is almost entirely dominated by smouldering, the MCE drops significantly, indicating that more smouldering combustion products have been sampled. For heading fires the transition from $30 \%$ smouldering combustion area to $\simeq 95 \%$ smouldering combustion area occurs in about $2 \mathrm{~min}$. In contrast, backing fires take about $12 \mathrm{~min}$ to achieve the same transition and flanking fires take at least $7 \mathrm{~min}$. The reduction of MCE as the fire transitions to purely smouldering (i.e. no flaming) is very dramatic $(<30 \mathrm{~s}$ for the heading fire).

The fact that the MCE value is close to unity for flaming combustion and that it reduces as the percentage area of smouldering combustion increases confirms that our results are successfully capturing the transitions that occur in the plume dynamics rather than being the result of a sampling artefact. We would expect a rapid transition from high to low MCE values (see Fig. 6) for heading fires, because the areal transition from flaming to predominantly smouldering combustion is so quick. Additionally, the areal transition from flaming to predominantly smouldering combustion is much slower for flanking and backing fires with this being represented by a slower (as expected) reduction in MCE. 
Furthermore, comparison of our results with other field and laboratory studies suggests that MCE does vary with respect to fire spread mode. This includes good agreement with the MCE trends found for different fire spread modes in the laboratory study of Keene et al. (2006) and good agreement with Wooster et al. (2011) (see Sect. 4.2) based on field sampling of heading and backing fires with an FTIR system in African savannas. Both of these studies, like ours, did not explore the relationship between MCE and sampling height and location in the plume. As the variation in burning conditions and combustion dynamics are quite significant (Mulvaney, 2012), full characterisation of the variation in emissions ratios across the exit section of our wind tunnel would require extensive testing at multiple, simultaneous sampling heights and locations, or a complete computational fluid dynamics simulation, both of which are beyond the scope of the current study.

\section{Conclusions}

This study has explored the hypothesis (which was formulated and tested statistically) that fire spread mode and phase of combustion can lead to differences in emissions factors of greenhouse gases from laboratory-scale fires conducted in a wind tunnel facility. We found that both fire spread mode and combustion phase had statistically significant impacts on emissions of greenhouse gases. Furthermore, the temporal progression of emissions factors were markedly different for the three different fire spread modes.

In particular, we found that flanking and backing fires emitted less $\mathrm{CO}_{2}$ and $\mathrm{CO}$ than heading fires, primarily due to the differences in percentage area undergoing smouldering combusting. Flanking and backing fires also had more carbon remaining in combustion residues on a per unit carbon basis due to less uniform flame front progression. These results have direct relevance to the management of forested landscapes that are affected by fire. Given the lower magnitude of greenhouse emissions species from flanking and backing fires this (potentially) opens up an opportunity to reduce carbon emissions from fire by the strategic use of these fire spread modes over heading fires. Future research activities could involve investigating greenhouse gas emissions for different fire spread modes but with more strata in the fuel bed which would better represent the way in which forest fuels burn in the field. In addition, the measurement of particulate emissions factors continues to be a significant avenue for future research, as well as quantification of emissions ratios with different fire behaviours and sampling heights and locations in the plume.

Author contributions. All authors were involved in the experimental design. N. C. Surawski, A. L. Sullivan and S. H. Roxburgh performed the experiments with guidance from P. J. Polglase. N. C. Surawski performed the data analysis with input from
A. L. Sullivan and C. P. Meyer. N. C. Surawski prepared the manuscript with contributions from all co-authors.

Acknowledgements. The authors thank Nigel England and Matthew Plucinski for their assistance during the experimental fires. This work was undertaken in the former greenhouse gas abatement and carbon storage in land use systems theme of the CSIRO Sustainable Agriculture Flagship. The authors wish to thank Michael Battaglia and Sandra Eady for their support of this project and their guidance.

Edited by: R. Holzinger

\section{References}

Akagi, S. K., Yokelson, R. J., Wiedinmyer, C., Alvarado, M. J., Reid, J. S., Karl, T., Crounse, J. D., and Wennberg, P. O.: Emission factors for open and domestic biomass burning for use in atmospheric models, Atmos. Chem. Phys., 11, 4039-4072, doi:10.5194/acp-11-4039-2011, 2011.

Andreae, M. O. and Merlet, P.: Emission of trace gases and aerosols from biomass burning, Glob. Biogeochem. Cy., 15, 955-966, doi:10.1029/2000gb001382, 2001.

Baer, D. S., Paul, J. B., Gupta, J. B., and O'Keefe, A.: Sensitive absorption measurements in the near-infrared region using offaxis integrated-cavity-output spectroscopy, Appl. Phys. B-Lasers Optics, 75, 261-265, doi:10.1007/s00340-002-0971-z, 2002.

Bowman, D. M. J. S., Balch, J. K., Artaxo, P., Bond, W. J., Carlson, J. M., Cochrane, M. A., D'Antonio, C. M., DeFries, R. S., Doyle, J. C., Harrison, S. P., Johnston, F. H., Keeley, J. E., Krawchuk, M. A., Kull, C. A., Marston, J. B., Moritz, M. A., Prentice, I. C., Roos, C. I., Scott, A. C., Swetnam, T. W., van der Werf, G. R., and Pyne, S. J.: Fire in the Earth System, Science, 324, 481-484, doi:10.1126/science.1163886, 2009.

Byram, G. M.: Combustion of forest fuels, in: Forest Fire Control and Use, edited by: Davis, K., 61-89, McGraw-Hill, New York, 1959.

Cai, W., Cowan, T., and Raupach, M.: Positive Indian Ocean Dipole events precondition southeast Australia bushfires, Geophys. Res. Lett., 36, L19710, doi:10.1029/2009gl039902, 2009.

Chatto, K. and Tolhurst, K.: The development and testing of the Wiltronics T-H fine fuel moisture meter, Research Report No. 46, Fire Management Branch, Department of Natural Resources and Environment, Melbourne, Victoria, 1997.

Cheney, N. P.: Fire behaviour, in: Fire and the Australian biota, edited by: Gill, A. M., Groves, R. H., and Noble, I. R., 151-176, The Australian Academy of Science, Canberra, 1981.

Christian, T. J., Yokelson, R. J., Carvalho, Jr., J. A., Griffith, D. W. T., Alvarado, E. C., Santos, J. C., Neto, T. G. S., Gurgel Veras, C. A., and Hao, W. M.: The tropical forest and fire emissions experiment: Trace gases emitted by smoldering logs and dung from deforestation and pasture fires in Brazil, J. Geophys. Res.Atmos., 112, doi:10.1029/2006JD008147, 2007.

Commonwealth of Australia: Australian National Greenhouse Accounts, National Inventory Report 2012, Vol. 2, Department of Environment, Canberra, 2014. 
Crutzen, P. J., Heidt, L. E., Krasnec, J. P., Pollock, W. H., and Seiler, W.: Biomass burning as a source of atmospheric gases $\mathrm{CO}, \mathrm{H}_{2}, \mathrm{~N}_{2} \mathrm{O}, \mathrm{NO}, \mathrm{CH}_{3} \mathrm{CL}$ and COS, Nature, 282, 253-256, doi:10.1038/282253a0, 1979.

Cruz, M., Sullivan, A., Gould, J., Sims, N., Bannister, A., Hollis, J., and Hurley, R.: Anatomy of a catastrophic wildfire: the Black Saturday Kilmore East fire in Victoria, Australia, Forest Ecol. Manag., 284, 269-285, doi:10.1016/j.foreco.2012.02.035, 2012.

Department of Agriculture: Australian Coastal Outline and Landmass with State Boundaries, available at: http://data.daff.gov.au/ anrdl/metadata_files/pa_nsaasr9nnd_02211a04.xml (last access: 16 April 2015), 2014.

Houghton, R. A., Hall, F., and Goetz, S. J.: Importance of biomass in the global carbon cycle, J. Geophys. Res.-Biogeo., 114, G00E03, doi:10.1029/2009jg000935, 2009.

Hurst, D. F., Griffith, D. W. T., Carras, J. N., Williams, D. J., and Fraser, P. J.: Measurements of trace gases emitted by Australian savanna fires during the 1990 dry season, J. Atmos. Chem., 18, 33-56, doi:10.1007/bf00694373, 1994a.

Hurst, D. F., Griffith, D. W. T., and Cook, G. D.: Trace gas emissions from biomass burning in tropical Australian savannas, J. Geophys. Res.-Atmos., 99, 16441-16456, doi:10.1029/94jd00670, 1994b.

Hurst, D. F., Griffith, D. W. T., and Cook, G. D.: Trace-gas emissions from biomass burning in Australia, in: Biomass burning and global change, edited by: Levine, J., Vol. 2, 787-792, The MIT Press, Cambridge, Massachussets, 1996.

Jenkins, B. M., Kennedy, I. M., Turn, S. Q., Williams, R. B., Hall, S. G., Teague, S. V., Chang, D. P. Y., and Raabe, O. G.: Windtunnel modeling of atmospheric emissions from agricultural burning - influence of operating configuration on flame structure and particle-emission factor for a spreading-type fire, Environ. Sci. Technol., 27, 1763-1775, doi:10.1021/es00046a002, 1993.

Keene, W. C., Lobert, J. M., Crutzen, P. J., Maben, J. R., Scharffe, D. H., Landmann, T., Hély, C., and Brain, C.: Emissions of major gaseous and particulate species during experimental burns of southern African biomass, J. Geophys. Res.-Atmos., 111, D04301, doi:10.1029/2005jd006319, 2006.

Le Canut, P., Andreae, M. O., Harris, G. W., Wienhold, F. G., and Zenker, T.: Airborne studies of emissions from savanna fires in southern Africa.1. Aerosol emissions measured with a laser optical particle counter, J. Geophys. Re.-Atmos., 101, 23615-23630, doi:10.1029/95jd02610, 1996.

Lee, T., Sullivan, A. P., Mack, L., Jimenez, J. L., Kreidenweis, S. M., Onasch, T. B., Worsnop, D. R., Malm, W., Wold, C. E., Hao, W. M., and Collett, Jeffrey, L. J.: Chemical smoke marker emissions during flaming and smoldering phases of laboratory open burning of wildland fuels, Aerosol Sci. Technol., 44, I-V, doi:10.1080/02786826.2010.499884, 2010.

Levine, J. and Cofer III, W.: Boreal forest fire emissions and the chemistry of the atmosphere, in: Fire, Climate Change, and Carbon Cycling in the Boreal Forest, edited by: Kasischke, E. S. and Stocks, B. J., 31-48, Springer-Verlag, New York, 2000.

Lobert, J. M., Scharffe, D. H., Hao, W. M., and Crutzen, P. J.: Importance of biomass burning in the atmospheric budgets of nitrogencontaining gases, Nature, 346, 552-554, doi:10.1038/346552a0, 1990.

Mack, M. C., Bret-Harte, M. S., Hollingsworth, T. N., Jandt, R. R., Schuur, E. A. G., Shaver, G. R., and Verbyla, D. L.: Carbon loss from an unprecedented Arctic tundra wildfire, Nature, 475, 489492, doi:10.1038/nature10283, 2011.

Matthews, S.: Effect of drying temperature on fuel moisture content measurements, Int. J. Wildland Fire, 19, 800-802, doi:10.1071/WF08188, 2010.

McArthur, A.: Control burning in eucalpyt forests, Forestry and Timber Bureau No. 80, Commonwealth of Australia, Canberra, 1962.

McArthur, A.: Fire Behaviour in Eucalpyt Forests, Forest and Timber Bureau Leaflet No. 107, Commonwealth of Australia, Canberra, 1967.

McMeeking, G. R., Kreidenweis, S. M., Baker, S., Carrico, C. M., Chow, J. C., Collett Jr., J. L., Hao, W. M., Holden, A. S., Kirchstetter, T. W., Malm, W. C., Moosmüller, H., Sullivan, A. P., and Wold, C. E.: Emissions of trace gases and aerosols during the open combustion of biomass in the laboratory, J. Geophys. Res.Atmos., 114, doi:10.1029/2009JD011836, 2009.

Meyer, C. P. and Cook, G. D.: Biomass combustion and emission processes in the Northern Australian Savannas, in: Carbon Accounting and Savanna Fire Management, edited by: Murphy, B., Edwards, A., Meyer, C. P., and Russell-Smith, J., 185-218, CSIRO Publishing, Collingwood, Australia, in press, 2015.

Meyer, C. P., Cook, G. D., Reisen, F., Smith, T. E. L., Tattaris, M., Russell-Smith, J., Maier, S. W., Yates, C. P., and Wooster, M. J.: Direct measurements of the seasonality of emission factors from savanna fires in northern Australia, J. Geophys. Res.Atmos., 117, D20305, doi:10.1029/2012jd017671, 2012.

Monks, P. S., Granier, C., Fuzzi, S., Stohl, A., Williams, M. L., Akimoto, H., Amann, M., Baklanov, A., Baltensperger, U., Bey, I., Blake, N., Blake, R. S., Carslaw, K., Cooper, O. R., Dentener, F., Fowler, D., Fragkou, E., Frost, G. J., Generoso, S., Ginoux, P., Grewe, V., Guenther, A., Hansson, H. C., Henne, S., Hjorth, J., Hofzumahaus, A., Huntrieser, H., Isaksen, I. S. A., Jenkin, M. E., Kaiser, J., Kanakidou, M., Klimont, Z., Kulmala, M., Laj, P., Lawrence, M. G., Lee, J. D., Liousse, C., Maione, M., McFiggans, G., Metzger, A., Mieville, A., Moussiopoulos, N., Orlando, J. J., O'Dowd, C. D., Palmer, P. I., Parrish, D. D., Petzold, A., Platt, U., Pöschl, U., Prévôt, A. S. H., Reeves, C. E., Reimann, S., Rudich, Y., Sellegri, K., Steinbrecher, R., Simpson, D., ten Brink, H., Theloke, J., van der Werf, G. R., Vautard, R., Vestreng, V., Vlachokostas, C., and von Glasow, R.: Atmospheric composition change - global and regional air quality, Atmos. Environ., 43, 5268-5350, doi:10.1016/j.atmosenv.2009.08.021, 2009.

Mulvaney, J.: The Inherent Variability of Fires in Naturally Heterogeneous Fuel Beds under Controlled Conditions, Honours thesis, Fenner School of Environment and Society, Australian National University, Canberra, 2012.

O'Keefe, A. and Deacon, D. A. G.: Cavity ring-down optical spectrometer for absorption-measurements using pulsed laser sources, Rev. Sci. Instrum., 59, 2544-2551, doi:10.1063/1.1139895, 1988.

Paton-Walsh, C., Smith, T. E. L., Young, E. L., Griffith, D. W. T., and Guérette, É.-A.: New emission factors for Australian vegetation fires measured using open-path Fourier transform infrared spectroscopy - Part 1: Methods and Australian temperate forest fires, Atmos. Chem. Phys., 14, 11313-11333, doi:10.5194/acp14-11313-2014, 2014.

Radke, L., Hegg, D., Lyons, J., Brock, C., and Hobbs, P.: Airborne measurements on smokes from biomass burning, in: Aerosols 
and climate, edited by: Hobbs, P. and Patrick McCormick, M., 411-422, A. Deepak Publishing, Hampton, Virginia, 1988.

Reid, J. S., Koppmann, R., Eck, T. F., and Eleuterio, D. P.: A review of biomass burning emissions part II: intensive physical properties of biomass burning particles, Atmos. Chem. Phys., 5, 799825, doi:10.5194/acp-5-799-2005, 2005.

Running, S. W.: Is global warming causing more, larger wildfires?, Science, 313, 927-928, doi:10.1126/science.1130370, 2006.

Seiler, W. and Crutzen, P. J.: Estimates of gross and net fluxes of carbon between the biosphere and the atmosphere from biomass burning, Climatic Change, 2, 207-247, doi:10.1007/bf00137988, 1980.

Sullivan, A. L. and Ball, R.: Thermal decomposition and combustion chemistry of cellulosic biomass, Atmos. Environ., 47, 133141, doi:10.1016/j.atmosenv.2011.11.022, 2012.

Sullivan, A. L. and Matthews, S.: Determining landscape fine fuel moisture content of the Kilmore East "Black Saturday" wildfire using spatially-extended point-based models, Environ. Model. Softw., 40, 98-108, doi:10.1016/j.envsoft.2012.08.008, 2013.

Sullivan, A. L., McCaw, W., Cruz, M., Matthews, S., and Ellis, P.: Fuel, fire weather and fire behaviour in Australian ecosystems, in: Flammable Australia: fire regimes, biodiversity and ecosystems in a changing world, edited by: Bradstock, R., Gill, A., and Williams, R., 51-77, CSIRO publishing, Collingwood, Victoria, 2012.

Sullivan, A. L., Knight, I. K., Hurley, R. J., and Webber, C.: A contractionless, low-turbulence wind tunnel for the study of free-burning fires, Exp. Therm. Fluid Sci., 44, 264-274, doi:10.1016/j.expthermflusci.2012.06.018, 2013.

Teague, B., McLeod, R., and Pascoe, S.: 2009 Victorian Bushfires Royal Commission, Final report summary, State of Victoria, Melbourne, Victoria, 2010.

Tolhurst, K. G. and Cheney, N. P.: Synopsis of the knowledge used in prescribed burning in Victoria, Department of Natural Resources and Environment, East Melbourne, Victoria, 1999.

Urbanski, S. P.: Combustion efficiency and emission factors for wildfire-season fires in mixed conifer forests of the northern Rocky Mountains, US, Atmos. Chem. Phys., 13, 7241-7262, doi:10.5194/acp-13-7241-2013, 2013.

van der Werf, G. R., Randerson, J. T., Giglio, L., Collatz, G. J., Mu, M., Kasibhatla, P. S., Morton, D. C., DeFries, R. S., Jin, Y., and van Leeuwen, T. T.: Global fire emissions and the contribution of deforestation, savanna, forest, agricultural, and peat fires (19972009), Atmos. Chem. Phys., 10, 11707-11735, doi:10.5194/acp10-11707-2010, 2010. van Leeuwen, T. T. and van der Werf, G. R.: Spatial and temporal variability in the ratio of trace gases emitted from biomass burning, Atmos. Chem. Phys., 11, 3611-3629, doi:10.5194/acp11-3611-2011, 2011.

van Leeuwen, T. T., Peters, W., Krol, M. C., and van der Werf, G. R.: Dynamic biomass burning emission factors and their impact on atmospheric CO mixing ratios, J. Geophys. Res.-Atmos., 118, 6797-6815, doi:10.1002/jgrd.50478, 2013.

Vicente, A., Alves, C., Monteiro, C., Nunes, T., Mirante, F., Evtyugina, M., Cerqueira, M., and Pio, C.: Measurement of trace gases and organic compounds in the smoke plume from a wildfire in Penedono (central Portugal), Atmos. Environ., 45, 5172-5182, doi:10.1016/j.atmosenv.2011.06.021, 2011.

Volkova, L., Meyer, C. P. M., Murphy, S., Fairman, T., Reisen, F., and Weston, C.: Fuel reduction burning mitigates wildfire effects on forest carbon and greenhouse gas emission, Int. J. Wildland Fire, 23, 771-780, doi:10.1071/WF14009, 2014.

Weinhold, B.: Fields and forests in flames: Vegetation smoke and human health, Environ. Health Persp., 119, A386-A393, doi:10.1289/ehp.119-a386, 2011.

Wooster, M. J., Freeborn, P. H., Archibald, S., Oppenheimer, C., Roberts, G. J., Smith, T. E. L., Govender, N., Burton, M., and Palumbo, I.: Field determination of biomass burning emission ratios and factors via open-path FTIR spectroscopy and fire radiative power assessment: headfire, backfire and residual smouldering combustion in African savannahs, Atmos. Chem. Phys., 11, 11591-11615, doi:10.5194/acp-11-11591-2011, 2011.

Yokelson, R. J., Goode, J. G., Ward, D. E., Susott, R. A., Babbitt, R. E., Wade, D. D., Bertschi, I., Griffith, D. W. T., and Hao, W. M.: Emissions of formaldehyde, acetic acid, methanol, and other trace gases from biomass fires in North Carolina measured by airborne Fourier transform infrared spectroscopy, J. Geophys. Res.-Atmos., 104, 30109-30125, doi:10.1029/1999jd900817, 1999.

Yokelson, R. J., Burling, I. R., Gilman, J. B., Warneke, C., Stockwell, C. E., de Gouw, J., Akagi, S. K., Urbanski, S. P., Veres, P., Roberts, J. M., Kuster, W. C., Reardon, J., Griffith, D. W. T., Johnson, T. J., Hosseini, S., Miller, J. W., Cocker III, D. R., Jung, H., and Weise, D. R.: Coupling field and laboratory measurements to estimate the emission factors of identified and unidentified trace gases for prescribed fires, Atmos. Chem. Phys., 13, 89-116, doi:10.5194/acp-13-89-2013, 2013. 